\title{
Structural Determination of the Glycan Part in Glycoproteins
}

\author{
糖タンパクのグリカン部分の構造決定 \\ Anne-Sophie ANGEL, Gunnar GRÖNBERG, \\ Göran NILSSON, Stefan STRÖMBERG, Ingela TAPPER and Bo NILSSON \\ The Glycoprint ${ }^{\mathrm{TM}}$ Group, BioCarb Technology AB, S - 22370 Lund, Sweden. FAX: 46-46-151395
}

\section{Introduction}

A new type of pharmaceuticals became available when the recombinant DNA technique was introduced. The development of cell systems for manufacturing of biologically important proteins, used in therapy and diagnosis, have focused the attention on protein glycosylation. Most of the events leading to $N$-glycosylation involving transfer of the lipid-linked oligosaccharide to asparagine in a certain amino acid sequence of the nascent protein and subsequent processing to the final products have been elucidated. The glycosylation pattern obtained depends on several factors such as cell types and growth conditions. An $N$-glycosylation site carries either a complex or a high mannose type of structure. Hybrid structures are sometimes found but in rather rare cases. Structural diversity is often prevalent resulting in presence of different structures (bi-, tri-, and tetraantennary) in the same glycosylation site. Furthermore, heterogeneity within the structures is common, due to partial substitution by sialic acid and fucose. This structural heterogeneity makes the isolation and the following structural analysis difficult.

$O$-Glycosylation means substitution of serine or threonine usually with $\mathrm{N}$-acetylgalactosamine in an $\mathrm{O}$-glycosidic linkage. Unlike the $N$-glycosylation no specific amino acid sequence is required for $O$-glycosylation. The $O$-linked carbohydrate chains are often smaller and structurally less complicated than the $N$-linked. The present paper summarizes methods for release, separation and structural analysis of $\mathrm{N}$ - and $\mathrm{O}$ linked glycoprotein oligosaccharides.

\section{Glycan Structure}

All $N$-linked glycans have a common trimannosyl chitobiose core structure of:

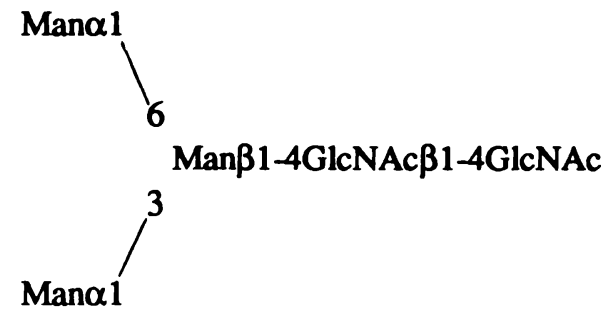

This structure can be substituted in various positions and to a
はじめに

リコンビナントDNA技街が開発されて新しいタイプ医 莱品が利用できるようになった。治㙩や診断に用いられる生物 学的に重要なタンパクの生産の為の細胞系の発達の耛果、タン パクのグリコシル化が注目されるようになった。 グリコシル 化されていないタンバクのあるアミノ列列のアスパラギンへ

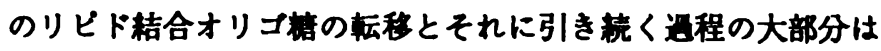
明らかにされた。グリコシル化は細胞の程類と培盖条件に传存 する。N-グリコシル化部位はコンブレックス型かハイマンノー ス型の㭗造を持つ。ハイブリッド型は時として見られるが、こ れは稀でる。㭗造の多栏性の䊅果、同一のグリコシル化部位 に異なった椎造(ビ-,トリ-,テトラアンテナリー)が存在する。更 に、シアール聡とフコースによる部分贯换に起因するへテロ ジニテイが同一粗造中に存在する。この㭗造のへテロジニ

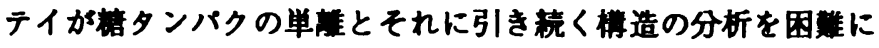
している。

O-グリコシル化とはセリン、スレオニンの通常N-フセチル ガラクトサミンによる兽换を意味する。N-グリコシル化とは異 なって゚-グリコシル化には特別なアミノ酸配は必要ではな い。この詥文ではN-、O-䊅合糖タンパク榶鎖の切り出し、分 流、そして椱造解析について概稓する。

\section{グリカンの粠造}

全てのN-䊅合桾鎖は共通のトリマンノシル キトビオース コア槽造:<smiles>[14CH3][Hg][18OH]</smiles>

$\operatorname{Man} \beta$ 1-4GlcNAc $\beta$ 1-4GlcNAc 
variable degree by the following residues and sequences:

Fuc

Man

GlcNAc

Gal $\alpha 1-3 \mathrm{Gal} \beta 1-4 \mathrm{GlcNAc}$

Neu5Ac $\alpha 2-3 \mathrm{Gal} \beta 1-4 \mathrm{GlcNAC}$

Neu5Ac $\alpha 2-6 \mathrm{Gal} \beta 1-4 \mathrm{GlcNAc}$

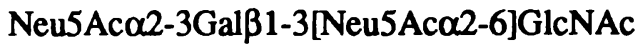

The high mannose structures are formed by substitution by multiple mannose residues and the complex types contain the sialylated sequences. Hybrid structures contain mannose residues on one of the branches and the monosialylated sequences on the other. Two or more $N$-acetyl-lactosamine (Galß1-4GlcNAc) sequences linked together form the polylactosamine type. The bisecting type is recognized by a GlcNAc residue linked $\beta 1-4$ to the 3,6-disubstituted Man residue.

The $O$-linked glycans contain a common GalNAc residue, which can be substituted by the following residue and sequences:

Neu5Ac

Neu5Aco2-3Gal JGalNAc

Neu5Ac $\alpha 2-3 \mathrm{Gal} \beta 1-4 \mathrm{GlcNAc}$

The above structures make up the majority of $\mathrm{N}$ - and $\mathrm{O}$-linked glycans. There are however some exceptional glycoproteins with unusual glycan structures differing from the above.

\section{Release of Glycans}

In order to carry out structural analysis the glycans have to be released from the protein and fractionated into pure compounds. The methods employed depend on the type of carbohydrate-protein linkage, e.g. $\mathrm{N}$ - or $\mathrm{O}$-linked carbohydrates. As an initial step for designing a suitable strategy, the intact glycoprotein is subjected to sugar analysis. Information about the monosaccharide composition and the total carbohydrate content will be helpful to decide how much glycoprotein is needed for the structural analysis. Furthermore, presence of GalNAc is in most cases diagnostic for $O$-linked and mannose for $N$-linked structures. $O$-Linked glycans are preferably released as alditols by alkaline borohydride degradation (1). $N$-Linked glycans can be released by chemical or enzymatic methods. The chemical methods include hydrazinolysis (2), alkaline borohydride under conditions for $N$-linked glycans (3) and trifluoroacetolysis (4). All chemical procedures, however, suffer from drawbacks due to formation of undesired degradation products specially at the reducing terminal of the released glycan. Several enzymatic methods are available that make use of peptidases and endo-glycosidases. Digestion with peptidases followed by separation of the glycopeptides offers a possibility to determine the glycosylation sites of the protein. Endo- $\beta$ - $N$-acetylglucosaminidases cleave between $N$-ace-
ハイマンノース構造は幾つかのマンノース残基で置换され ており、コンブレックス型はシアール酸の䊅合した配列を有し ている。ハイブリド型は一つの分岐にマンノース残基を持ち、 他の分岐にシアール酸が䊅合している。2ケ以上のN-アセチルラ クトサミン(Gal $\beta$ 1-4GlcNAc)配列はポリラクトサミン型構造を 形作る。バイセクテイング型では3,6-貫換されたManにGlcNAc が $\beta$ 1-4䊅合している。

O-䊅合グリカンは共通なGalNAcを持ち、これは次の残基と 配列で暑换されている:

Neu5Ac

Neu5Ac $\propto$ 2-3Gal JGalNAc

Neu5Ac $\alpha 2-3$ Gal $\beta$ 1-4GlcNAc

上にのべた構造がN-及びO-桔合グリカンの大部分を占める。し かしながら、上に述へたものとは異なる例外的な棈造を持った 糖タンパクも幾つか存在する。

グリカンの切り出し

グリカンの粠造解析をする為にはグリカンはタンバクから 切り出され、純粋な化合物として分画されねばならない。その 方法は榶-タンパクの䊅合様式、すなわちN-あるいはO-耛合榶鎖 に依存する。適当な戦略を立てる第一歩として、檔タンバクは 梠の組成分析を行う。単榶と全梠分析は分析にとのくらいの糖 タンパクが必要か決定するのに役立つ。更に、GalNAcの存在は 大低の場合、O-䊅合榶鎖、Manの存在はN-䊅合糖鎖の目安とな る。O-䊅合糖鎖はアルカリボロハイドライド分解でアルジトール として切り出されるのが好ましい(1)。

$\mathrm{N}$-耛合桾鎖は化学的、酳素的方法で切り出される。化学的 方法としてはヒドラジン分解(2)、N-䊅合榶鎖向きのアルカリボ ロハイドライド処理(3)、トリフルオロアセトリシス(4)が知られ ている。しかしながら、全ての化学的方法は切り出されたグリ カンの這元末端で生成する好ましくない分解物を生成するとい う欠点を持っている。ベブチダーゼ、エンドグリコシダーせを利 用する酳素的方法が利用される。ペブチダーゼを用いて分解 し、それに秸いてグリコペブチドを分錐すると、タンパクの可 能なグリコシル化部位を決定できる。エンド- $\beta$-N-アセチルグル コサミニターゼはN-,N'-キトビオース配列のGlcNAc残基間の䊅 合を切断し、逐元末端にGlcNAcを持ったオリゴ糖を生成する。 インタクトなN-グリカンはPGNエース[ペプチド- $\mathrm{N}^{4}(\mathrm{~N}-$ アヤチル

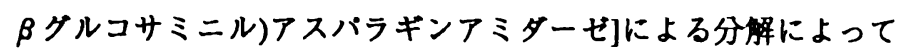
得られる。これらのエンド醅素の特異性については文献(5)を参 照されたい。酵素的方法は副産物を生成せず、それに続く精 製、分部を容易にするので、しばしば魀力的な選択である。

\section{グリカンの分教}

詰タンバクがN-、O-䊅合糖鎖の両方を持っている時、アルカ リボロハイドライド処理によって切り出されたO-グリカンはNグリカンからゲルロ過で分讙できるこの場合、N-グリカンは 部分的に分解したタンパクに耛合している。オリコ榶アルシト ールの分權は更にイオン交換クロマトグラフィーあるいはHPLC 
tylglucosamine residues in the $N, N^{\prime}$-diacetylchitobiose sequence and oligosaccharides with reducing terminal GlcNAc residue are formed. Intact $N$-linked glycans can be obtained by digestion with HPNG-ases [peptide- $\mathrm{N}^{4}(N$-acetyl- $\beta$ glucosaminyl)asparagine amidase]. The specificity of these endo enzymes can be found elsewhere (5). Enzymatic methods are often attractive choices, since no sideproducts are formed making the subsequent purification and separation easier.

\section{Separation of Glycans}

When the glycoprotein contains both $\mathrm{N}$ - and $\mathrm{O}$-linked glycans the $O$-linked structures, released by alkaline borohydride, can be separated by gel filtration from the $N$-linked, which are still linked to the partially degraded protein. Further separation of the oligosaccharide alditols can be achieved by ion exchange chromatography or HPLC. Liberated $N$-linked oligosaccharides or glycopeptides can be fractionated using immobilized lectins such as Concanavalin A (Con A) to give three fractions, an unbound (tri- and tetraantennary) and two eluted with Me- $\alpha$-mannoside at concentrations of $15 \mathrm{mM}$ (biantennary) and $200 \mathrm{mM}$ (high-mannose), respectively (6). The Con A fractions can be further separated by high performance ion exchange chromatography (HPIEC). An example of the type of separation obtained is demonstrated in Fig. 1 by some tetrasialylated triantennary oligosaccharide alditols from bovine fetuin (7). The structures are separated according to the sialic acid linkages.
によって行われる。切り出されたN-䊅合オリコ榶、あるいは桔 ペブチドは不溶化されたレクチンで分画できる例えばコンカ ナバリンA(Con A)を用いると3つのフラクション、未吸着のフ ラクション(トリ-、テトラアンテナリー)と、 $15 \mathrm{mM}$ のチル $a$ マンノシドで溶出されるフラクション(パイアンテナリー)と $200 \mathrm{mM}$ のメチル $а$ マンノシドで溶出されるフラクション(ハイ マンノース)に分けられる(6)。これらのCon Aフラクションは更 に、ハイパフォーマンスイオン交换クロマトグラフィー (HPIEC)によって分㴰可能てる。図1にウシフェツインからの テトラシアリレーテッドトリアンテナリーオリコ梠アルシトー ルの分椎の一示した(7)。これらの構造はシアール酸の䊅合 に従って分樹された。

\section{糗造分析}

単誰された化合物は棬造分析を受ける。完全な構造の同定 の為には次の点が明らかにされねばならない:

1. 単粭組成

2. 配榙体䊅合の位置

3. 単榶残基のリングサイス

4. 䊉对配座

5. 単桾の配列

6. アノメリックコンフィグレーション

7. 糖澌以外の構成成分

8. タンパクのグリコシル化部位

それらの構造は化学分析、質量分析、'H-NMR分析からの データの組み合わせで決まる。ウシフェツインから単離された

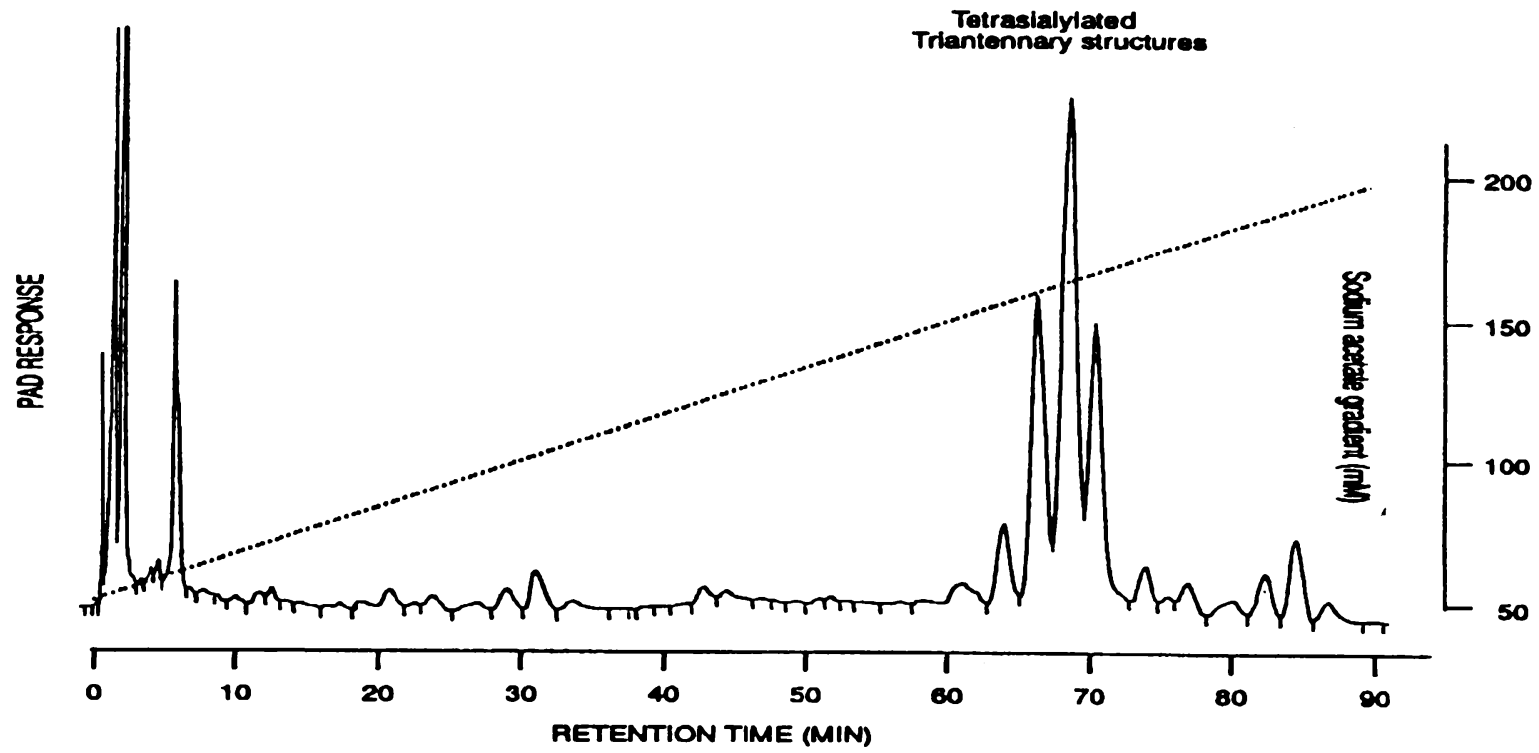

Fig. 1. Separation on HPIEC of tetetrasialylated triantennary oligosaccharide alditols. PAD, pulsed amperometric detection. 


\section{Structural Analysis}

Isolated compounds are subjected to structural analysis. In order to arrive at a complete structural identification the following points have to be addressed:

1. Monosaccharide composition

2. Positions of glycosidic linkages

3. Ring size of the monosaccharide residues

4. Absolute configuration

5. Monosaccharide sequence

6. Anomeric configuration

7. Non-carbohydrate substituents

8. Glycosylation sites of the protein

The structures are deduced from combined data obtained from chemical analyses, mass spectrometry and ${ }^{1} \mathrm{H}$ NMR spectroscopy. Some commonly occurring $\mathrm{N}$ - and $\mathrm{O}$ linked oligosaccharide alditols, isolated from bovine fetuin, are chosen to illustrate the data obtained from the spectroscopic methods $(7,8)$.

\section{Chemical Analysis}

The monosaccharide composition and the relative proportions of the residues can be determined by gas liquid chromatography (GLC) after acid hydrolysis and derivatization (9). Sialic acid cannot be determined by this procedure due to its lability to strong acids. Quantification of sialic acid is therefore performed using for example enzymatic or colorimetric methods (10). Binding positions between monosaccharide residues are determined by methylation analysis, (11). The derivatives are characterized by gas liquid chromatography-mass spectrometry (GLC-MS) and identified by GLC by comparison of retention times with standard compounds. The methylation analysis also gives information about the ring size of the monosaccharide residues i.e. pyranosides and furanosides. Absolute configuration of the monosaccharide residues can be determined by GLC of peracetylated glycosides prepared in the presence of 2-(t)-octanol (12). If glycopeptides have been obtained by proteolytic digestion and subsequent separation the glycosylation sites of the protein can be determined after amino acid analysis.

\section{Fast Atom Bombardment Mass Spectrometry}

The monosaccharide sequence and the molecular weight (M) can be determined, after permethylation, by fast atom bombardment mass spectrometry (FAB-MS). Additional structural information in terms of binding positions between monosaccharide residues can be obtained by carrying out, prior to analysis by FAB-MS, the following reaction steps; a) periodate oxidation $b$ ) reduction with $\mathrm{NaBD}_{4}$ c) peracetylation or permethylation $(13,14)$. The monosaccharide sequence and the binding
いくつかのこく普通のN-、及びO-桔合オリコ桾アルジトールに ついてのスペクトル法からのデータが文献 $(7,8)$ に示されてい る。

I. 化学分析

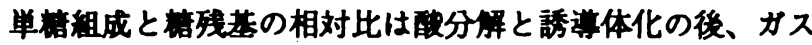
クロマトグラフィー(GLC)により決定される(9)。シフール橖は

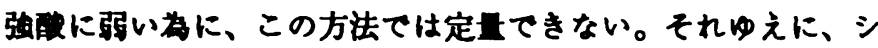
アール酸の定青には䤃素的方法、あるいは比色法が用いられる (10)。単詰間の桔合位是はメチル化分析で決定される(11)。メチ ル化化合物はカススマスで分析され、栖制物颃とリテンションタ イムを比數してGLCで同定される。メチル化分析は又、単榶の リングサイス、すなわちビラノースかフラノースについての情 辄を与える。単格残基の郶対配座は2-(+)オクタノールの存在下 で調紫された眍詰体のアセチル化誘算体のGLC分析により決定 でる(12)。もし詰ベブチドがタンバク分解醉素による分解と それに繶ずく分椎によって得られるならば、タンパクのダリコ シル化の部位をアミノ酸分析の後に決定てきる。

\section{FABマス分析(FAB-MS)}

単嵣の配列と分子量はメチル化の後、FAB-MSで決定でき る。単詰間の耛合位国はFAB-MS分析の前に次の反応ステッブに より得られる; a)䧟ヨーソ酸化、b)NaBD アセチレーションあるいはパーメチレーション $(13 、 14)$ 。単䊉の 配列と䊅合位亘は1次と 2 次の配列イオンから決定てきる。配列 イオンは配榙体秸合の開裂から生成する。

上に速べられた反応ステッブで得られたテトラシアリレー テッドトリアンテナリー構造のFABマススペクトルを図2に示 した。 $\mathrm{m} / \mathrm{z} 289$ と $\mathrm{m} / \mathrm{z}$ 698の1次配列イオンと、 $\mathrm{m} / \mathrm{z}$ 698からメ夕 ノールが除去されて生成した $\mathrm{m} / \mathrm{z}$ 666の2次配列イオンから Neu5Ac2-6Gal1-4GlcNAcの配列が決定された。もう1つの Neu5Ac2-3Gal1-4GlcNAcの配列はm/z 289、 $\mathrm{m} / \mathrm{z}$ 493、 $\mathrm{m} / \mathrm{z}$ 706、 $\mathrm{m} / \mathrm{z} 738$ の次、2次の配列イオンから決定された。ここで/ z 706はm/z 738からメタノールの除去で生成した。2つのシア ール酸の䊅合した眍列、Neu5Ac2-3Gal1-3[Neu5Ac2-6]GlcNAcは イオン $\mathrm{m} / \mathrm{z} 289 、 \mathrm{~m} / \mathrm{z} 493, \mathrm{~m} / \mathrm{z}$ 1013から決定された。退元末端 のGlcNAcへの䊅合位量を決定する為に帛元化合物の過ヨーソ酸 戝化がなされなければならない。通元された末端のイオン、m/ z 233 と $\mathrm{m} / \mathrm{z}$ 478は息元されたGlcNAcの4の位要がう1つの GlcNAcで是換されていることを示す。Man残基への䊅合位贯は このスペクトルからは䊅論できないか、後て述べる'H-NMRから その情辄が得られる。[M+23]+-イオン、m/z 3553はNeu5Ac23Galの末端町列を持った2つの分岐とNeu5Ac2-6Galの配列を 持った1つの分枝を有するテトラシアリレーテッドトリアンテナ リー槽造に一致する。

上述の方法がNeu5Ac $\alpha$ 2-3Gal $\beta$ 1-3[Neu5Ac $\alpha 2-6]$ GalNAc01の檄造を持つ0-䊅合オリコ榶アルシトールに適用され た.GalNAc-olは3、6て是換されているのて、過ヨーソ酸酸化の 後、GalNAc-olのC4とC6の䊅合が開裂し、2つの化合物が生成す ろ。C3の位要に䊅合している分岐はN-アセチルスレオサミニト 
positions of the glycosidic linkages are determined from the primary and secondary sequence ions. The sequence ions are formed by cleavage of the glycosidic bonds.

A FAB-mass spectrum of a tetrasialylated triantennary structure obtained after the above reaction steps is shown in Fig. 2. The primary sequence ions of $\mathrm{m} / \mathrm{z} 289$ and $698 \mathrm{com}$ bined with a secondary ion of $m / z 666$, formed by elimination of methanol from $\mathrm{m} / \mathrm{z} 698$, determine a sequence of Neu5Ac26Gal1-4GlcNAc. Another branch with a sequence of Neu5Ac2-3Gal1-4GlcNAc is deduced from the primary and secondary sequence ions of $\mathrm{m} / \mathrm{z} 289,493,706$ and 738 , where the $\mathrm{m} / \mathrm{z} 706$ ion is formed by elimination of methanol from $\mathrm{m} /$ $z$ 738. A disialylated sequence of Neu5Ac2-3Gal13[Neu5Ac2-6]GlcNAc is determined by the ions of $\mathrm{m} / \mathrm{z} 289$, 493 and 1013. In order to determine the binding position to the reducing terminal GlcNAc the periodate oxidation has to be carried out on the reduced compound. Ions from the reduced terminal of $\mathrm{m} / \mathrm{z} 233$ and 478 show that the reduced GlcNAc is substituted in the 4-position by another GlcNAc residue. The binding positions to the Man residues cannot be deduced from the spectrum, but this information is provided by ${ }^{1} \mathrm{H}-\mathrm{NMR}$ as discussed below. An $[\mathrm{M}+23]^{+}$-ion of $\mathrm{m} / \mathrm{z} 3553$ is consistent with a tetrasialylated triantennary structure with two branches terminated with a sequence of Neu5Ac2-3Gal and one branch with a Neu5Ac2-6Gal sequence.

The above method was applied on an $O$-linked oligo-
ールをアグリコンとして持ち、C6の位昷に桔合している分伎は エチレングリコールを末端に持つ(15)。アセチル化の後に分析 すると、図3(スペクトルA)に示したFAB-MSスペクトルが得ら れた。残基のC2の水酸基とのラクトン形成の為に週ヨーン 酸化て分解されたシフール酸の存在を示す配列イオンの存在 は钼繁されなかった(15)。N-アセチルスレオサミニトールはm/ z 231、 $\mathrm{m} / \mathrm{z} 545$ の配列イオン、 $\mathrm{m} / \mathrm{z}$ 793の[M+1]+イオンで同定 されるのて、Neu5Ac2-3Galの配列はGalNAc-olの3の位鲳に䊅合 していると桔詥てきる。 $\mathrm{m} / \mathrm{z} 362$ の $[\mathrm{M}+1]^{+}$イオンはエチレング リコールに喆合し、更にラクトンを介在しているNeu5Acのもの てある。それめえに、元の糖鎖ではGalNAc-olの6位はNeu5Acに よって是换されていなければならない。メチル化化合物のFABMSはm/z 289, 493の配列イオンがNeu5Ac2-3Galに特徽的であ ることを示している(図3、スペクトルB)メチル化によってラクト ンは開理した。N-アセチルスレオサミニトールに相当するイオ ンはm/z 189てある。 m/z 699の[M+1]+イオンはアセチル化サン フルの先に述ベたデータを指示する。メチル化サンフルては Neu5Ac-エチレングリコールを同定する特別なイオンは锶察さ れなかった。

O-アセチルグループ、リン酸、硫酸といった非榶啠昷换基 が楉タンバクに锤察される。上述の方法はこれらの㥁換基の耛 合位是を決定するのに有効である。

\section{III. 'HNMR 分析}

'HNMRは更に構造に関する証拠を与え、FAB-MSで得られ たデータを確認する。高分解能'HNMRは非破丧分析法であり、
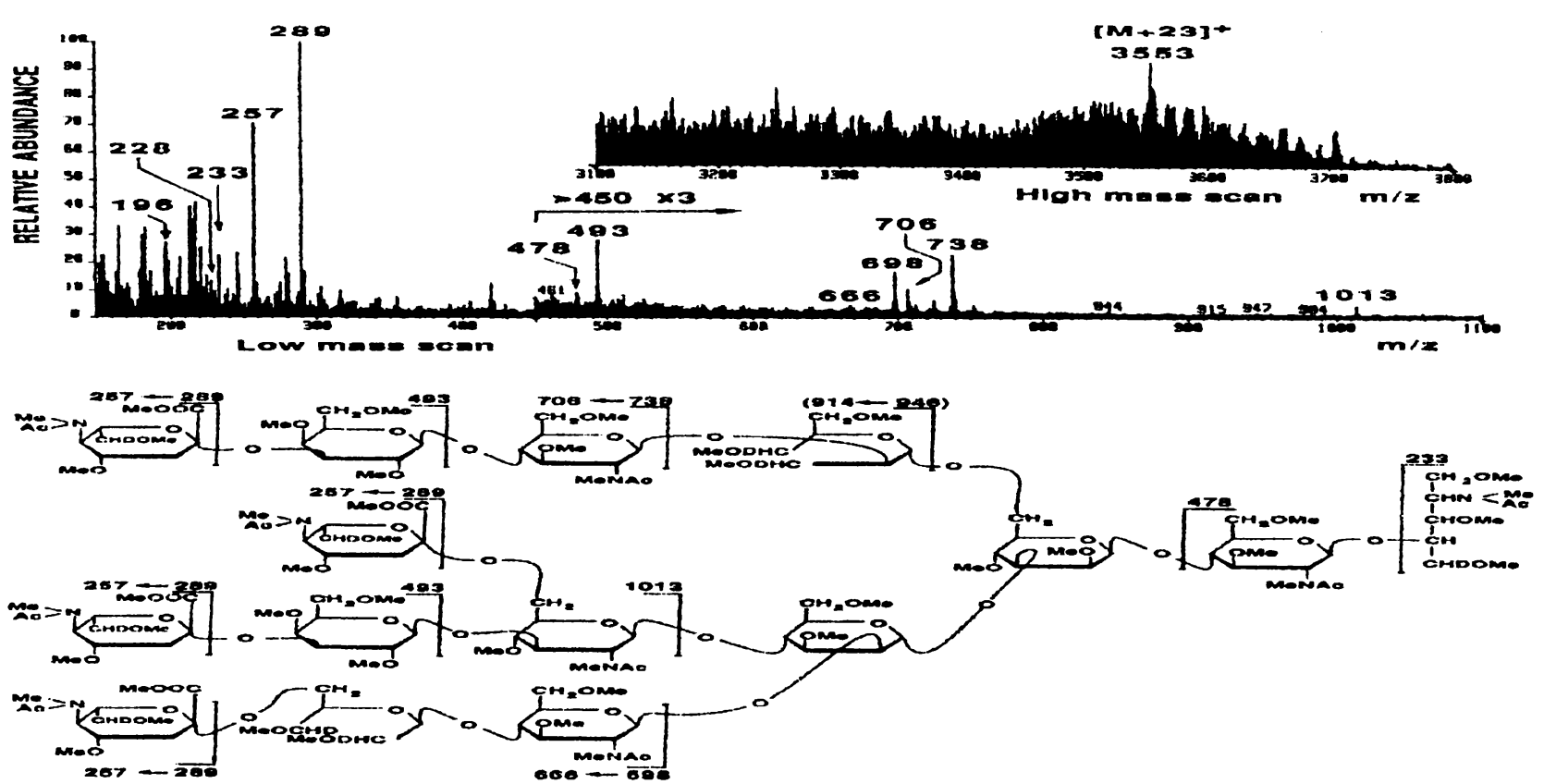

Fig. 2. FAB-mass spectrum of a tetrasialylated trianntennary oligosaccharide alditol after perodate oxidation, $\mathrm{NaBD}_{4}$-reduction and permethylation. The high mass scan was recorded separately and in the presence of sodium iodide. 
saccharide alditol with a structure of Neu5Ac $\alpha 2-3 \mathrm{Gal} \beta 1$ 3[Neu5Aco2-6]GalNAc-ol. Since the GalNAc-ol is 3,6-disubstituted two products will be formed, after periodate oxidation, by cleavage between carbons 4 and 5 within the alditol. The branch connected to the 3-position will have $N$-acetylthreosaminitol as aglycon and the branch linked to the 6-position will be terminated with ethylene glycol (15). Analysis of the products after acetylation gave a FAB-mass spectrum shown in Fig. 3 (spectrum A). No sequence ions indicating a periodate degraded sialic acid are seen, due to lactone formation involving the hydroxyl at carbon 2 of the $\mathrm{Gal}$ residue (15). The $N$-acetylthreosaminitol is recognized by the ion of $\mathrm{m} / \mathrm{z} 231$ and combined with a sequence ion of $\mathrm{m} / \mathrm{z} 545$ and an $[M+1]^{+}$-ion of $\mathrm{m} / \mathrm{z}$ 793, it can be concluded that the Neu5Ac2-3Gal sequence occupies the 3-position of the GalNAc-ol. An [M+1]+-ion of $\mathrm{m} / \mathrm{z}$ 362 is consistent with a Neu5Ac linked to ethylene glycol and further connected via a lactone. The 6-position of the GalNAcol must therefore, in the native compound, be substituted by a Neu5Ac residue. FAB-MS of the permethylated compound shows sequence ions of $\mathrm{m} / \mathrm{z} 289$ and 493 specific for a Neu5Ac2-3Gal sequence (Fig. 3, spectrum B). During the methylation procedure the lactone was opened. The corresponding ion for the $N$-acetylthreosaminitol is $\mathrm{m} / \mathrm{z} 189$. An $[\mathrm{M}+1]^{+}$-ion of $\mathrm{m} / \mathrm{z} 699$ supports the previous data on the acetylated sample. No specific ions identifying the Neu5Ac-ethylene glycol are seen in the permethylated sample.

Non-carbohydrate substituents like $O$-acetyl groups, phosphates and sulfates are sometimes found in glycoproteins.
誘導体化されていないサンブルに対して、D 型的なトリアンテナリー構造では $15 \mathrm{nmol}(15 \mu \mathrm{g})$ の量で分析が行 われる。棬造の情報は込みあったリングブロトンの領域から離れ たシグナルから成る構造情報グルーブから主として決められる。

構造情報グルーブは単榶のタイプ、アノメリックコンフィ グレーション、他の榶残基や非糖質置换基との䊅合位鲳とコン フォーメーションの変化に対してセンシテイブである。

次の共鳴はN-あるいはO-グリカンの共通の構造情報グルー プ例である: Man残基のH-1とH-2、GlcNAc, GalNAc, Fucと GalのH-1、シアール酸のH-3(ax)とH-3(eq)、FucとN-アセチル基 のCH${ }_{3}(16)$ 。

図4にテトラシアリレーテッドトリアンテナリー棈造の $500 \mathrm{MHz}$ スベクトルが示されている。GlcNAcのCH $\mathrm{CH}_{3}$ のつのシ グナルが観察され、Man4とMan4'のH-1に対するケミカルシフ 卜 (5.131 ppmと4.902 ppm) と特にMan3とMan4とMan4 'のH-2 に対するケミカルシフト(4.222 ppm, $4.222 \mathrm{ppm}, 4.12 \mathrm{ppm})$ は Man4'にa1-6䊅合した1つの分岐とMan4に $\alpha$ 1-3䊅合した2つの 分岐を持ったトリアンテナリー構造を示す。4つのシアール酸が 存在し、その2つは $\alpha 2-3 て ゙ G a l k$ 䊅合し(H-3ax/H-3eq; 1.805/ $2.758 \mathrm{ppm}$ と1.786/2.758 ppm)、その1つは $\alpha$ 2-6でGalに䊅合し (H-3ax/H-3eq; 1.727/2.671 ppm)ている。Man4とMan4'のH-1に 对するケミカルシフト、5.131 ppmと4.902 ppmは $\alpha$ 1-3結合し たMan4残基の2の位置に䊅合した分岐の $\alpha$ 2-6シアール酸と、 $\alpha$ 1-6䊅合したMan4 '残基に䊅合した分岐の $\alpha$ 2-3シアール酸に相 当する。従って、 $\alpha 1-3$ 䊅合したMan4の4の位置に䊅合した分岐 には末端に 2-3シアール酸が䊅合している。第4番目のシアー
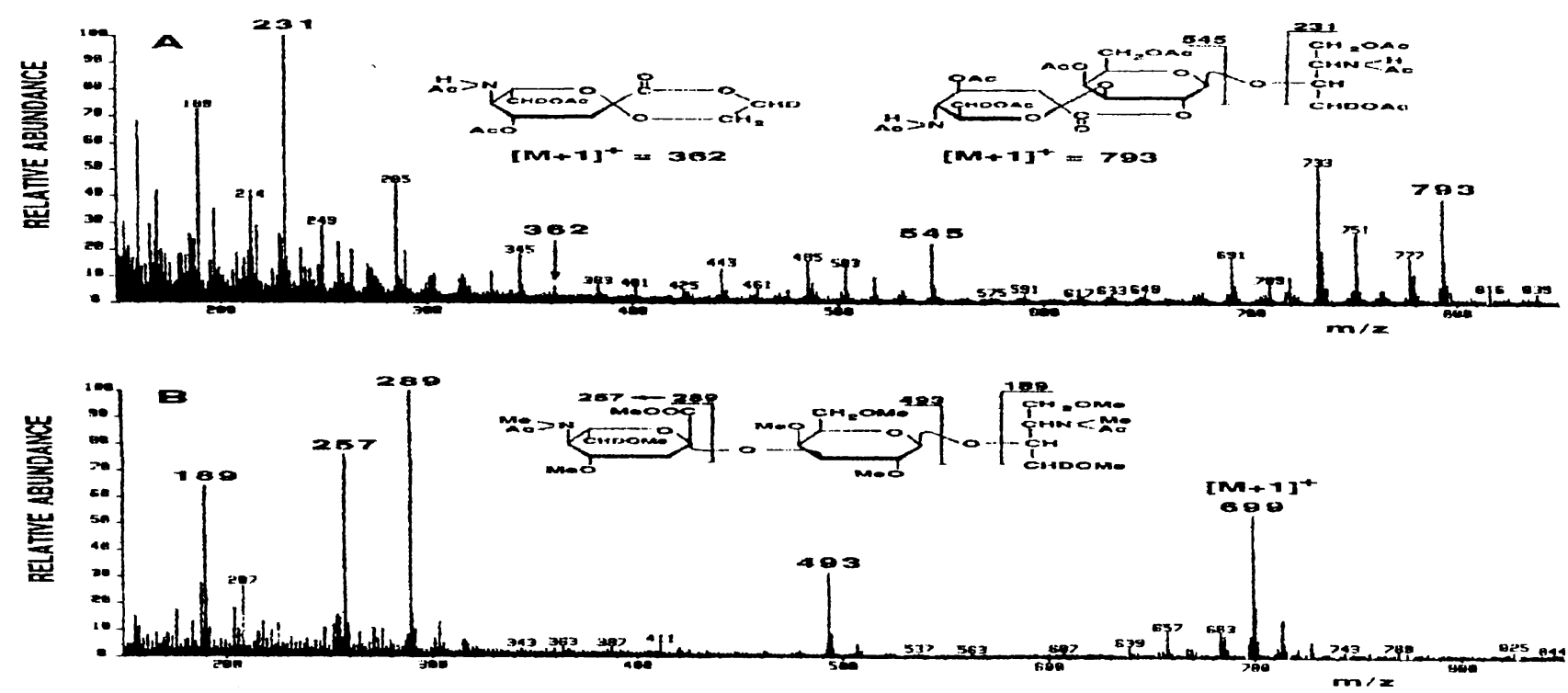

Fig. 3. FAB-mass spectra of an $O$-linked disialylated tetrasaccharide alditol after periodate oxidation, $\mathrm{NaBD}_{4}$-reduction, and peracetylation(A) and permethylation(B). 
The above method can be useful to determine binding positions of these substituents.

\section{III. ${ }^{1} \mathrm{H}-\mathrm{NMR}$ spectroscopy}

${ }^{1} \mathrm{H}-\mathrm{NMR}$ Spectroscopy gives further evidence for the structure and confirms the previously obtained data. High resolution ${ }^{1} \mathrm{H}-\mathrm{NMR}$ is a non destructive analytical method and is performed on the underivatized sample, dissolved in $\mathrm{D}_{2} \mathrm{O}$, requiring about $15 \mathrm{nmol}(50 \mu \mathrm{g})$ of a typical triantennary structure.

The structural information is primarily deduced from the structural reporter groups consisting of signals shifting out from the crowded region of overlapping ring protons. The structural reporter groups are sensitive to several features in the structure such as type of monosaccharide, anomeric configuration, binding positions of other sugar residues or non-carbohydrate substituents and conformational changes.

The following resonances are examples of common reporter groups in $N$ - or $O$-linked glycans: $\mathrm{H}-1$ and $\mathrm{H}-2$ of the Man residues, H-1 of GlcNAc, GalNAc, Fuc and Gal, H-3 axial (ax) and $\mathrm{H}-3$ equatorial (eq) of sialic acid, $\mathrm{CH}_{3}$ signals of Fuc and $\mathrm{N}$-acetyl groups (16).

A $500 \mathrm{MHz}{ }^{1} \mathrm{H}$-spectrum of the tetrasialylated triantennary structure is shown in Fig. 4. Five signals from GlcNAc $\mathrm{CH}_{3}$ groups are found and the chemical shifts for H-1 of Man4 and Man4' (5.131 and 4.902 ppm) and especially H-2 of Man3, Man4 and Man4' (4.222, 4.222 and 4.12 ppm) indicate a triantennary structure with one branch connected to the $\alpha 1-6$ linked
ル酸に対する粠造情報グルーブ(H-3ax/H-3eq; $1.765 / 2.729$ ppm) と4.499 ppmの $\beta \mathrm{Gal}$ のアノメリックプロトンのケミカルシフト は $\alpha$ 1-3䊅合したMan4の4の位置に䊅合したNeu5Ac $\alpha$ 2-3Gal $\beta$ 13[Neu5Ac $\alpha$ 2-6]GlcNAc $\beta$ の存在を示す。これらのデータは以前 に発表された䊅果(7)と一致する。

4 桾アルジトールのスペクトルが図5に示されてい ろ.GalNAc-olの4.379 ppm(H-2), 4,240ppm(H-5), $2.042 \mathrm{ppm}\left(\mathrm{CH}_{3}\right)$ のシグナルはシアール酸による6の位置の置換(H-3ax/H3eq; $1.692 / 2.723 \mathrm{ppm}, \mathrm{CH}_{3} ; 2.031 \mathrm{ppm}$ )と $\beta \mathrm{Gal} に よ ろ 3 の$ 位置 の贯換を示している。 $4.541 \mathrm{ppm}$ と4.117 ppmのGal残基のH-1と H-3のケミカルシフトはそれぞれこのGalk $\alpha$ 2-3䊅合した第2の シアール酸の存在 $(\mathrm{H}-3 \mathrm{ax} / \mathrm{H}-3 \mathrm{eq} ; 1.799 / 2.774 \mathrm{ppm})$ を示してい る。これらのデータは以前の発表(17)と一致する。

\section{BTG /帝京大学医学部}

川口吉太郎 訳
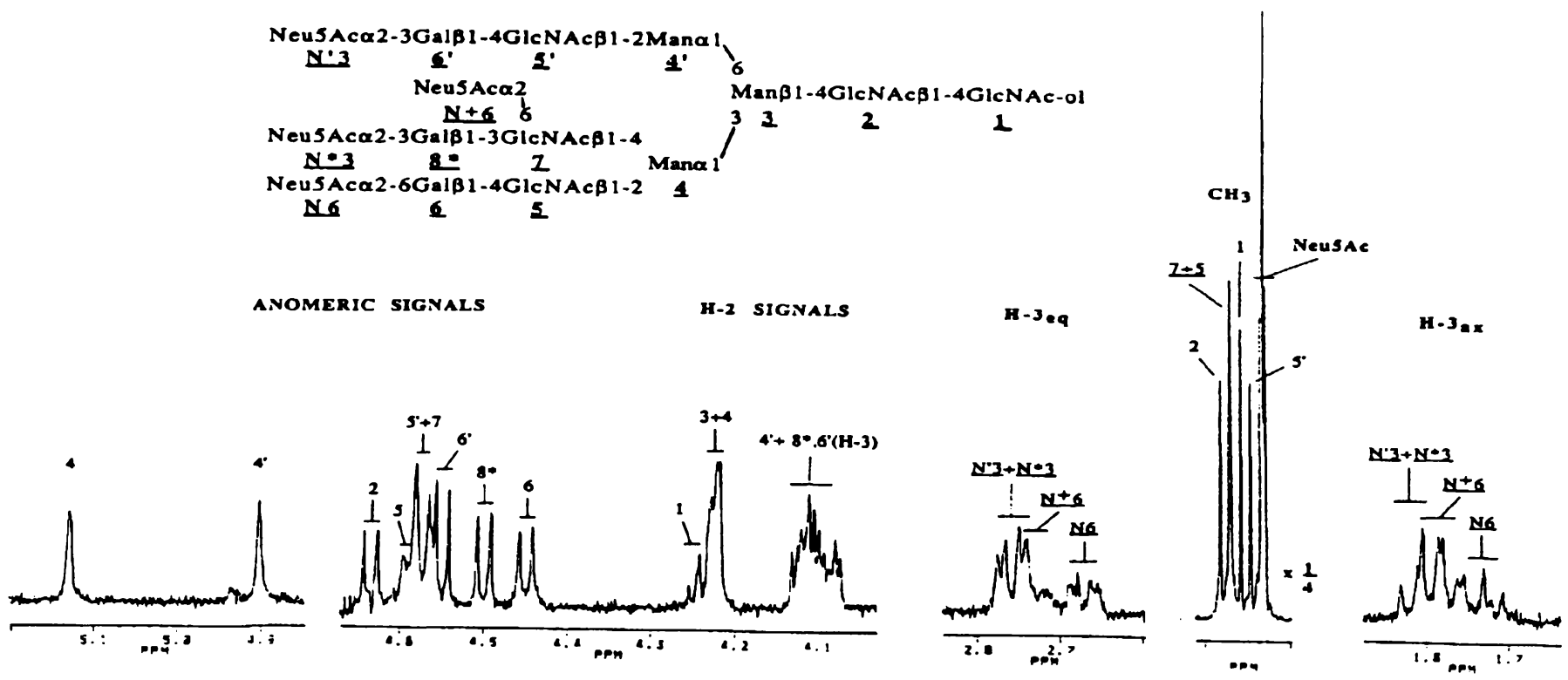

Fig. 4. A $500 \mathrm{MHz}{ }^{1} \mathrm{H}$-NMR spectrum of a tetrasialylated triantennary oligosaccharide alditol. 

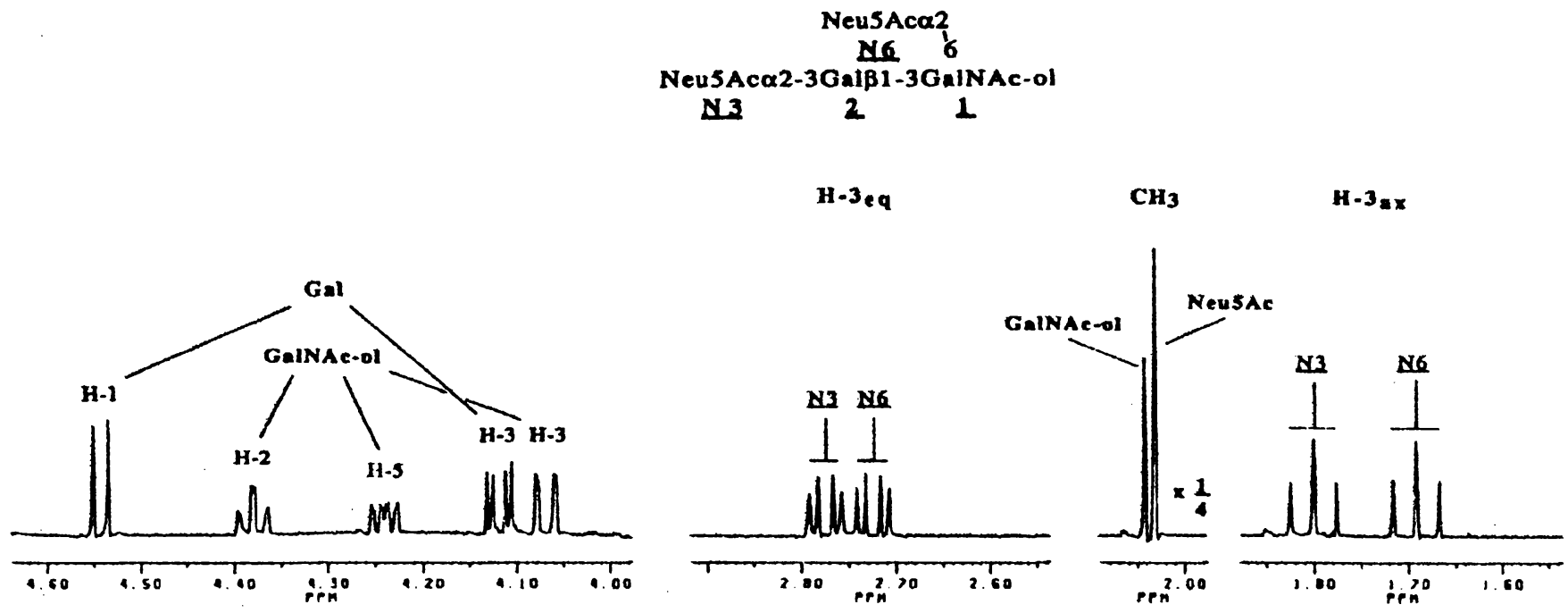

Fig. 5. A $500 \mathrm{MHz}{ }^{1} \mathrm{H}$-NMR spectrum of an O-linked disialylated tetrasaccharide alditol.

Man4' and two branches linked to the $\alpha 1-3$ linked Man4 residue. Four residues of sialic acid are present, two linked $\alpha 2-3$ to $\mathrm{Gal}(\mathrm{H}-3 \mathrm{ax} / \mathrm{H}-3 \mathrm{eq} ; 1.805 / 2.758$ and $1.786 / 2.758 \mathrm{ppm})$ and one linked $\alpha 2-6$ to Gal (H-3ax/H-3eq; 1.727/2.671 ppm). The chemical shifts for H-1 of Man4 and Man4' at 5.131 ppm and $4.902 \mathrm{ppm}$ are in accordance with an $\alpha 2-6$ linked sialic acid on the branch bound to the 2-position of the $\alpha 1-3$ linked Man4 residue, and an $\alpha 2-3$ linked sialic acid on the branch connected to the $\alpha 1-6$ linked Man4' residue. Consequently the branch attached to the 4-position of the $\alpha 1-3$ linked Man4 is terminated with an $\alpha 2-3$ linked sialic acid. The reporter groups for the fourth sialic acid residue $\mathrm{H}-3 \mathrm{ax} / \mathrm{H}-3 \mathrm{eq}$ at $1.765 / 2.729 \mathrm{ppm}$, together with a typical shift for a $\beta G$ al-anomeric signal at

\section{References}

$4.499 \mathrm{ppm}$ indicate a sequence of Neu5Aco2-3Gall$3[$ Neu5Ac $\alpha 2-6]$ GlcNAc $\beta$ linked to the 4-position of the $\alpha 1-3$ linked Man4 residue. These data are in agreement with previously published (7).

A spectrum of the tetrasaccharide alditol is presented in Fig. 5. The signals from the GalNAc-ol at $4.379 \mathrm{ppm}(\mathrm{H}-2)$, $4.240 \mathrm{ppm}(\mathrm{H}-5)$ and $2.042 \mathrm{ppm}\left(\mathrm{CH}_{3}\right)$ indicate substitution of this residue in the 6-position by sialic acid (H-3ax/H-3eq; $1.692 / 2.723 \mathrm{ppm}, \mathrm{CH}_{3} ; 2.031 \mathrm{ppm}$ ), and in the 3-position by a $\beta$-linked $\mathrm{Gal}$ residue. Judged by the chemical shifts for $\mathrm{H}-1$ and $\mathrm{H}-3$ of the Gal residue at $4.541 \mathrm{ppm}$ and $4.117 \mathrm{ppm}$, respectively, a second Neu5Ac residue is linked $\alpha 2-3$ to this galactose (H-3ax/H-3eq; 1.799/2.774 ppm). The data obtained are in agreement with previous findings (17).

1. Carlson, D.M. (1966) J. Biol. Chem. 241, 2984-2986

2. Yoshizawa, Z., Sato, T., and Schmid, K. (1966) Biochem. Biophys. Acta 121, 417-420

3. Lee, Y.C., and Scocca, J.R. (1972) J. Biol. Chem. 247, 5753-5758

4. Nilsson, B., and Svensson, S. (1979) Carbohydr. Res. 72, 183-189

5. Maley, F., Trimble, R.B., Tarentino, A.L., and Plummer Jr., T.H. (1989) Anal. Biochem. 180, 195-204

6. Debray, H., Decout, D., Strecker, G., Spik, G., and Montreuil, J. (1981) Eur. J. Biochem. 117, 41-55

7. Green, E.D., Adelt, G., Baenziger, J.U., Wilson, S., and van Halbeek, H. (1988) J. Biol. Chem. 263, 18253-18268

8. Nilsson, B., Norden, N.E., and Svensson, S. (1979) J. Biol. Chem. 254, 4545-4553

9. Sawardeker, J.S., Sloneker, J.H., and Jeanes, A.R. (1965) Anal. Chem. 37, 1602-1604

10. Jourdian, G.W., Dean, L., and Roseman, S. (1976) J. Biol. Chem. 246, 430-435

11. Björndal, H., Hellerqvist, C.G., Lindberg, B., and Svensson, S. (1970) Angew. Chem. Int. Ed. Engl. 9, 610-619

12. Leontein, K., Lindberg, B., and Lönngren, J. (1978) Carbohydr. Res. 63, 359-362

13. Angel, A-S., Lindh, F., and Nilsson, B. (1987) Carbohydr. Res. 168, 15-31

14. Angel, A-S., and Nilsson, B. (1990) Methods Enzymol. 193, 587-607

15. Krotkiewski, H., Lisowska, E., Angel, A-S., and Nilsson, B. (1988) Carbohydr. Res. 184, 27-38

16. Vliegenthart, J.F.G., Dorland, L., and van Halbeek, H. (1983) Adv. Carbohydr. Chem. Biochem. 41, 209-374

17. van Halbeek, H., Dorland, L., Vliegenthart, J.F.G., Fiat, A-M., and Jolle's, P. (1981) FEBS Let. 133, 45-50 